\title{
Análise financeira das instituições bancárias tradicionais e 100\% digitais: uma comparação de desempenho.
}

\section{Victor de Miranda A. Ferreira*, Luiz Eduardo Gaio.}

\begin{abstract}
Resumo
A inovação tecnológica tornou-se aliada na dinâmica da vida humana. Dentro de Finanças, o preceito é o mesmo. Sendo assim, o presente estudo quantificou e comparou, por meio da estatística descritiva e da regressão linear, o desempenho financeiro entre as instituições bancárias tradicionais e as Fintechs. Os resultados mostram que ROE, lucratividade, endividamento total e crescimento das Fintechs estão com evolução superior aos indicadores obtidos das instituições tradicionais. As Fintechs possuem menor risco de falência, estão aumentando o seu endividamento total e o fato de ser $100 \%$ digital influencia no retorno positivo do ROE. Como conclusão, pode-se afirmar que, no geral, o desempenho financeiro das Fintechs evolui a uma taxa superior ao desempenho das instituições tradicionais.
\end{abstract}

Palavras-chave: Instituições bancárias, Fintech, Análise financeira.

\section{Introdução}

Com a importância da internet na sociedade, o aumento exponencial de telefones móveis em todo o mundo, a chegada da geração $Y$ ao mercado consumidor e de produtos e serviços totalmente centrados e personalizados no cliente, o uso de serviços do Mobile Banking, entre 2011 e 2016, passou de 100 milhões de transações para mais de 22 bilhões de movimentações ${ }^{1}$. O mercado passa por transformações cujas características estão interligadas às mudanças disruptivas. Nesse contexto, surgem os bancos $100 \%$ digitais, atualmente denominados de Fintechs. Schueffel define o termo Fintech como uma nova indústria financeira que aplica tecnologia para melhorar as atividades financeiras ${ }^{2}$.

Dessa forma, o presente estudo pretende fazer uma análise quantitativa e comparativa de desempenho financeiro entre as instituições tradicionais e as Fintechs.

\section{Resultados e Discussão}

$\mathrm{Na}$ composição do presente trabalho, sete indicadores foram construídos: ROE; \% da receita representando o Market; lucratividade; endividamento total; índice de Basiléia; crescimento; e tamanho das instituições. Para isso, utilizaram-se dados dispostos nas demonstrações contábeis consolidadas sob as normas da BR-GAAP, entre os exercícios anuais de 2009 a 2018.

$\mathrm{Na}$ análise da estatística descritiva dos indicadores, verificou-se que o ROE, a lucratividade, o endividamento total e o crescimento das Fintechs estão com expansão superior aos dados obtidos das instituições tradicionais. Os indicadores de tamanho e Market mostraram considerável superioridade dos bancos tradicionais. Por outro lado, o índice de Basiléia determinou que as Fintechs possuem menor risco de falência do que as instituições bancárias tradicionalistas.

Essa primeira análise nos permite inferir que 0 mercado das Fintechs será mais próspero e que o planejamento estratégico das instituições tradicionais tende a caminhar na direção total do Mobile Banking.

No que tangem as regressões lineares, os dados corroboraram com a análise descritiva. Considerando o ROE como variável dependente e $89,26 \%$ das variáveis analisadas explicando-o, verificou-se que o fato da instituição ser $100 \%$ digital influencia, necessariamente, no retorno positivo do ROE. E que as variáveis de controle TAMANHO e LUCRAT interferem fortemente na condição da variável dependente (ROE).
Tendo BASILÉIA como variável dependente, constatou-se que as variáveis analisadas explicam-no em $21,03 \%$. As variáveis de controle TAMANHO e CRESC não influenciam no risco de solvência. Já as variáveis LUCRAT e MARKET influem na determinação do índice referencial da variável dependente.

O pilar do ENDIVIDAMENTO TOTAL como variável dependente obteve $40,05 \%$ das variáveis estudadas explicando-o. Pode-se afirmar que a variável de controle TAMANHO induz fortemente na modificação da variável dependente. Ou seja, na medida em que a instituição cresce, o seu índice de endividamento total avoluma de forma proporcional.

Tabela 1. Regressão linear com os dados em painel.

\begin{tabular}{|c|c|c|c|c|c|c|}
\hline V. DEPEN $^{1}$ & \multicolumn{2}{|c|}{ ROE } & \multicolumn{2}{c|}{ BASILÉIA } & \multicolumn{2}{c|}{ END. TOTAL } \\
\hline V. CONTR $^{2}$ & Coef & Prob & Coef & Prob & Coef & Prob \\
\hline TAMANHO & $24 \%$ & $18 \%$ & $-282 \%$ & $99 \%$ & $612 \%$ & $100 \%$ \\
\hline CRESC & $0.4 \%$ & $94 \%$ & $-0.7 \%$ & $95 \%$ & $0.8 \%$ & $98 \%$ \\
\hline LUCRAT & $106 \%$ & $100 \%$ & $21 \%$ & $98 \%$ & $-22 \%$ & $98 \%$ \\
\hline MARKET & $-66 \%$ & $98 \%$ & $38 \%$ & $94 \%$ & $-73 \%$ & $99 \%$ \\
\hline DUMMY $^{3}$ & $4 \%$ & $99 \%$ & $-6.1 \%$ & $99 \%$ & $8.5 \%$ & $100 \%$ \\
\hline R $^{2}$ ajust $^{4}$ & \multicolumn{3}{|c|}{$89.26 \%$} & \multicolumn{2}{|c|}{$21.03 \%$} & \multicolumn{2}{c|}{$40.05 \%$} \\
\hline
\end{tabular}

Notas: (1) foram selecionadas três variáveis dependentes: ROE, índice de Basiléia e endividamento total; (2) tamanho, crescimento, lucratividade Market são as variáveis de controle; (3) Dummy mostra quanto a mais a Fintech teve de impacto; (4) evidencia o quanto as variáveis analisadas explicam a variável dependente.

\section{Conclusões}

Como conclusão deste estudo único e inovador, pode-se afirmar que, no geral, o desempenho financeiro das Fintechs evolui a uma taxa superior ao desempenho das instituições bancárias tradicionais. $O$ modelo de negócio do setor bancário passa por uma grande revolução e quem não acompanhar esse movimento com processos inovativos alinhados a demanda de mercado, certamente caminhará ao estado de insolvência total.

\section{Agradecimentos}

Agradeço à $\mathrm{CNPq}$ e à UNICAMP pela oportunidade de contribuir com o desenvolvimento da pesquisa no país.

\footnotetext{
${ }^{1}$ FEBRABAN. Pesquisa de Tecnologia Bancária, 2017. Disponível em <http://www.ciab.org.br/download/researches/research-2017.pdf>. Acesso em: 19 abr. 2018.

SCHUEFFEL, Patrick. Taming the beast: A Scientific Definition of Fintech. Journal of Innovation Management JIM, v. 4, n. 4, p. 32-54, 2016.
} 